\title{
Intrapleural streptokinase in the management of empyema
}

\author{
R F H Taylor, M B Rubens, M C Pearson, N C Barnes
}

\begin{abstract}
Background - Significant morbidity and mortality result from the ineffective evacuation of empyema. Failure of conventional first line treatment with closed intercostal tube drainage and antibiotic therapy may result in fibrin deposition and loculated empyema. Enzymatic debridement using intrapleural instillation of streptokinase is a non-invasive therapeutic option which may obviate the need for surgical intervention.

Methods - Eleven adults with multiloculated post-pneumonic empyemas who had failed to respond satisfactorily to intercostal tube drainage and antibiotic therapy were treated with intrapleural streptokinase between November 1992 and January 1994. A small catheter was inserted under ultrasound guidance into a loculation within the pleural space. Aliquots of 250000 units of streptokinase in $100 \mathrm{ml}$ normal saline were instilled into the pleural cavity and the tube clamped for four hours. Response was assessed by clinical outcome, measurement of drain output after unclamping, and subsequent pleural ultrasound, chest radiography, or both.

Results - Streptokinase enhanced drainage in all patients. Complete resolution of the empyema with re-expansion of the underlying lung was effected in eight patients, all of whom remain well. Further resolution of minimal pleural thickening was shown on subsequent chest radio-
\end{abstract}

graphs. Two patients with considerably thickened visceral pleura following empyema drainage underwent successful decortication. The other, with myocarditis and a pyopneumothorax, underwent surgery for non-resolution of the pneumothorax but died perioperatively from cardiac failure. The number of streptokinase instillations per patient ranged from two to six (median three), and the volume of empyema fluid drained per patient ranged from $100 \mathrm{ml}$ to $4870 \mathrm{ml}$ (median $900 \mathrm{ml}$ ). Streptokinase was well tolerated in all patients.

Conclusions - Intrapleural streptokinase is an effective adjunct in the management of complicated empyema and may reduce the need for surgery.

(Thorax 1994;49:856-859)

Thoracic empyemas continue to cause substantial morbidity and mortality ${ }^{1}$ despite the advent of antimicrobial therapy in the 1940s. Failure of conventional first line therapy namely, intercostal tube drainage and antibiotics - occurs when pleural fluid is no longer free flowing. Inadequate drainage is usually associated with the fibrinopurulent stage of the empyema process, in which empyema fluid becomes multiloculated by the formation of fibrin strands. Fibrin deposition within the pleural cavity may take only a few days. ${ }^{2}$ Thus patients may present with multiloculated effusions which are not amenable to tube drainage

\begin{tabular}{|c|c|c|c|c|c|c|c|c|c|c|}
\hline $\begin{array}{l}\text { Patient } \\
\text { no. }\end{array}$ & Sex & $\begin{array}{l}\text { Age } \\
\text { (years) }\end{array}$ & $\begin{array}{l}\text { Predisposing } \\
\text { factor }\end{array}$ & $\begin{array}{l}\text { Pleural } \\
\text { culture }\end{array}$ & $\begin{array}{l}\text { Days from } \\
\text { first drainage to } \\
\text { streptokinase } \\
\text { instillation }\end{array}$ & $\begin{array}{l}\text { Number of } \\
\text { streptokinase } \\
\text { instillations }\end{array}$ & $\begin{array}{l}\text { Volume of } \\
\text { fluid drained } \\
\text { (ml) }\end{array}$ & $\begin{array}{l}\text { Duration of } \\
\text { stay after } \\
\text { streptokinase } \\
\text { (days) }\end{array}$ & $\begin{array}{l}\text { Factors } \\
\text { complicating } \\
\text { recovery after } \\
\text { steptokinase }\end{array}$ & Outcome \\
\hline 1 & $\mathbf{F}$ & 25 & Smoker & - & 7 & 3 over 4 days & 1180 & 5 & - & Well at 56 weeks \\
\hline 2 & $\mathbf{M}$ & 26 & Myocarditis & $\begin{array}{l}\text { Clostridium } \\
\text { perfringens, } \\
\text { Pneumocystis } \\
\text { carinii }\end{array}$ & 43 & 3 over 3 days & 1160 & - & $\begin{array}{l}\text { Severe } \\
\text { cardiac } \\
\text { failure }\end{array}$ & $\begin{array}{l}\text { Surgery, died } \\
\text { postoperatively }\end{array}$ \\
\hline 3 & $\mathbf{M}$ & 26 & Smoker & - & 28 & 3 over 4 days & 360 & - & - & $\begin{array}{l}\text { Surgery, successful } \\
\text { decortication }\end{array}$ \\
\hline 4 & $\mathbf{M}$ & 39 & Drug abuser & - & 63 & 2 over 3 days & 100 & 4 & - & $\begin{array}{l}\text { Well at } 8 \text { weeks (lost to } \\
\text { follow up) }\end{array}$ \\
\hline 5 & $\mathbf{M}$ & 40 & Smoker & - & 42 & 3 over 4 days & 900 & 6 & - & Well at 30 weeks \\
\hline 6 & $\mathbf{M}$ & 48 & $\begin{array}{l}\text { Infected } \\
\text { pulmonary } \\
\text { infarction }\end{array}$ & $\begin{array}{l}\text { Escherichia } \\
\text { coli, } \\
\text { Bacteriodes }\end{array}$ & 5 & 3 over 5 days & 280 & 21 & $\begin{array}{l}\text { Malnourished, } \\
\text { fractured tibia } \\
\text { and fibula }\end{array}$ & Well at 6 weeks \\
\hline 7 & $\mathbf{M}$ & 55 & $\begin{array}{l}\text { Cardiac } \\
\text { failure }\end{array}$ & $\begin{array}{l}\text { Staphylococcus } \\
\text { aureus }\end{array}$ & 10 & 6 over 20 days & 4870 & 42 & $\begin{array}{l}\text { Cardiac, renal } \\
\text { failure and surgery } \\
\text { for strangulated } \\
\text { inguinal hernia }\end{array}$ & Well at 18 weeks \\
\hline 8 & $\mathbf{M}$ & 59 & - & $\begin{array}{l}\text { Mycobacterium } \\
\text { tuberculosis }\end{array}$ & .90 & 5 over 35 days & 1980 & - & - & $\begin{array}{l}\text { Surgery, successful } \\
\text { decortication }\end{array}$ \\
\hline 9 & $\mathbf{F}$ & 63 & $\begin{array}{l}\text { Rheumatoid } \\
\text { arthritis, } \\
\text { methotrexate }\end{array}$ & - & 2 & 2 over 2 days & 100 & 7 & - & Well at 5 weeks \\
\hline 10 & $\mathbf{M}$ & 66 & - & - & 49 & 4 over 7 days & 1160 & 12 & - & Well at 24 weeks \\
\hline 11 & $\mathbf{F}$ & 74 & Asthma & $\begin{array}{l}\text { Streptococcus } \\
\text { milleri }\end{array}$ & 4 & 2 over 2 days & 580 & 40 & $\begin{array}{l}\text { Malnourished, } \\
\text { fractured wrist }\end{array}$ & Well at 22 weeks \\
\hline
\end{tabular}



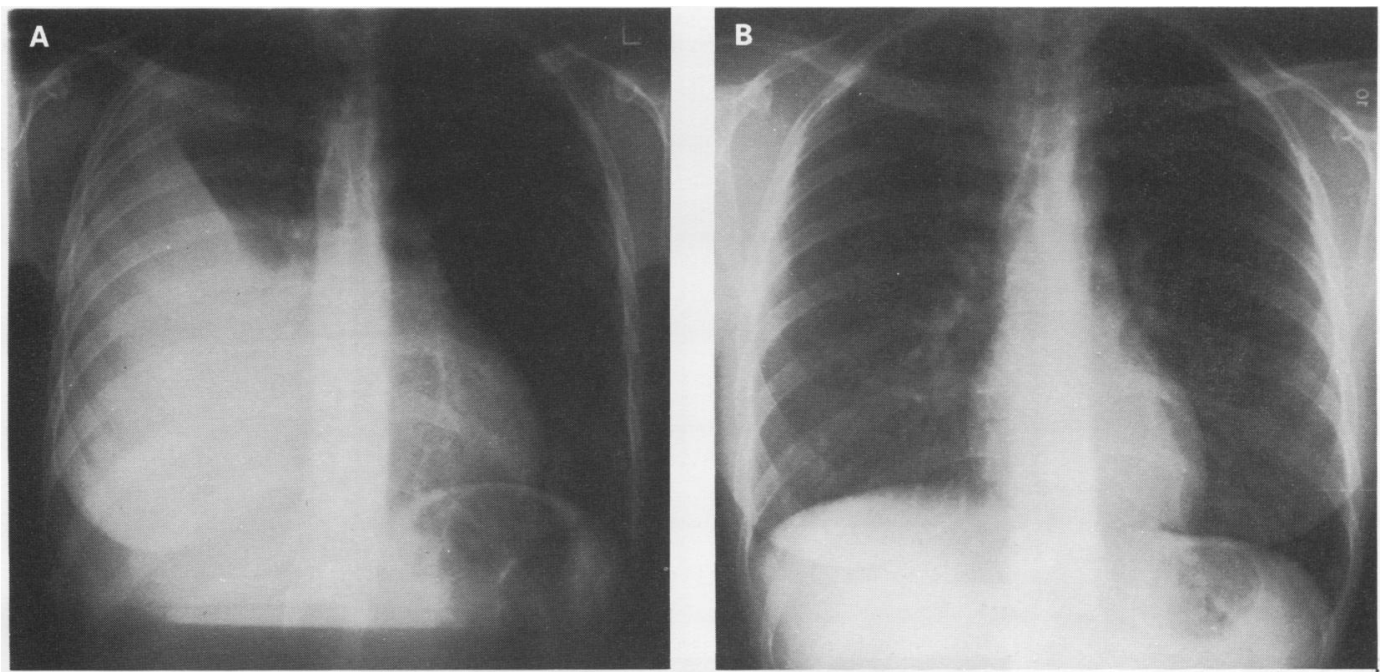

Figure 1 Chest radiographs of patient 1 (A) at presentation and (B) 40 weeks after treatment with streptokinase.

alone. In an attempt to facilitate drainage and obviate surgery, enzymatic debridement of the pleural cavity with streptokinase is a noninvasive therapeutic option. Intrapleural instillation of streptokinase was first described in 1949 by Tillet and Sherry. ${ }^{3}$ Its use did not gain acceptance, however, because of the rare occurrence of intrapleural haemorrhage and systemic fibrinolysis. ${ }^{45}$ With the availability of purer fibrinolytic formulations there has been a resurgence in the use of intrapleural fibrinolytic therapy ${ }^{6-8}$ in countries outside the UK. We have reviewed our experience of enzymatic lysis of adhesions in the pleural cavity with streptokinase in 11 patients with complicated empyemas.

\section{Methods \\ PATIENTS}

Eleven adults (eight men) of mean age 47 years (median 48, range 25-74) with multiloculated empyemas were treated with intrapleural streptokinase. All patients had post-pneumonic empyemas and had failed to respond satisfactorily to antibiotics and intercostal tube drainage. Pleural ultrasound examinations confirmed the presence of multiple loculations in all patients. In order to maximise fluid drainage prior to the instillation of streptokinase, all catheters (either 8 FG pigtail nephrostomy tube with 10 side holes or 14 FG double-lumen: Merck, Hampshire, UK) were inserted under ultrasound or fluoroscopic control into the largest loculation of fluid and were regularly flushed once or twice daily with $20 \mathrm{ml}$ normal saline to maintain patency. Suction had been applied to the drains of six patients before streptokinase was given. Two patients (nos 2 and 11) had more than one drain in situ at the time of streptokinase instillation; the second catheter was inserted under ultrasound guidance into the largest loculation which was separate from the area already drained. The underlying predisposing factors and pleural pathogens are listed in the table. Despite ultrasound guided placement of catheters, the use of suction, and the maintenance of tube patency, drainage was considered to be inadequate and so streptokinase was instilled into the pleural cavity.

\section{ADMINISTRATION OF STEPTOKINASE}

Aliquots of 250000 units streptokinase in $100 \mathrm{ml}$ normal saline were instilled into the pleural cavity via the small catheter and the tube(s) clamped. Patients were then rotated in various positions to improve the dispersal of streptokinase and the clamp(s) were released after four hours. Maximum drainage was achieved by assiduously maintaining the patency of the catheters by flushing. Maximum expansion was achieved by placing the drains on to negative pressure $\left(10-20 \mathrm{~cm} \mathrm{H}_{2} \mathrm{O}\right)$ suction before drain removal. The response to streptokinase was assessed by (a) clinical outcome (reduction in pain, dyspnoea, cough, and fever, and improvement in general wellbeing); (b) quantity of output from drain after unclamping; and (c) subsequent pleural ultrasound and serial chest radiography. Repeat instillation of streptokinase was performed if residual fluid was present 24 hours after the previous instillation.

\section{Results}

Complete resolution with re-expansion of the underlying lung was effected in eight patients. The mean follow up period was 20 weeks (range 5-56 weeks, median 20 weeks). All eight remain well and further resolution of minimal pleural thickening was shown in subsequent chest radiographs (figs 1-3). One patient, a 59 year old man with thickened visceral pleura in whom complete re-expansion did not occur following drainage of a chronic tuberculous empyema of 10 weeks duration, underwent successful decortication. A 26 year old man with a 10 week history of unresolved empyema drained $360 \mathrm{ml}$ fluid after streptokinase. In view of persisting thickened visceral pleura identified on ultrasound examination, however, decortication was performed. A 26 year old man 

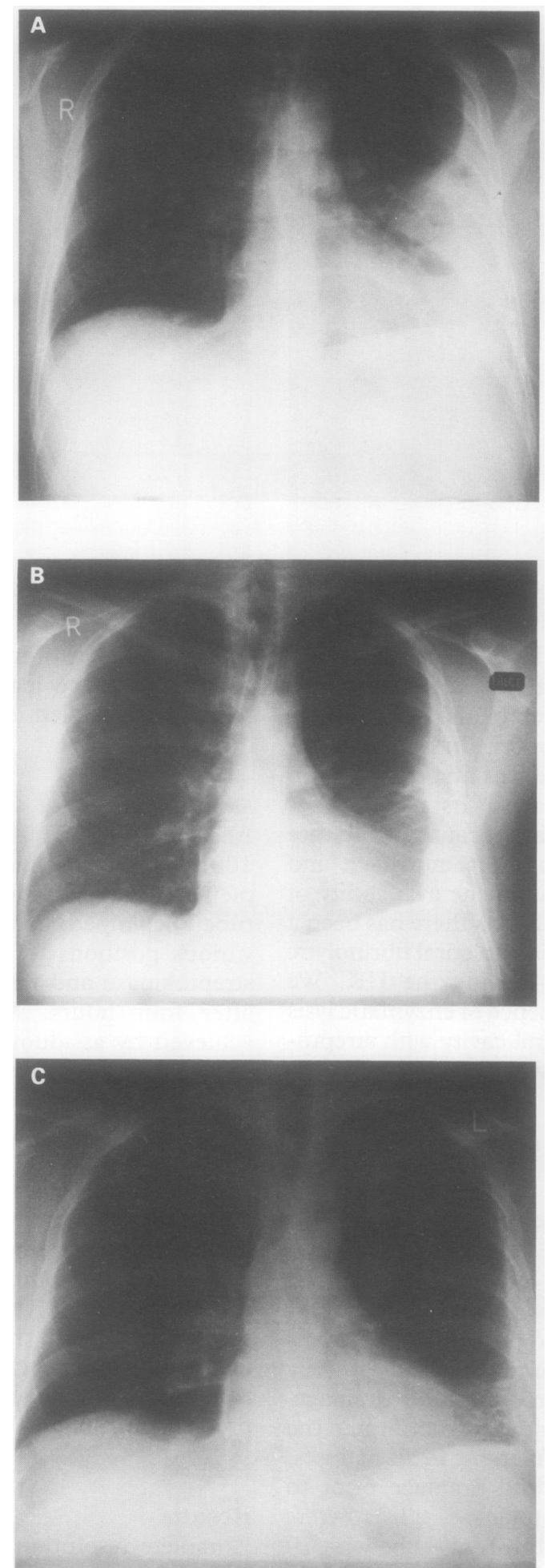

Figure 2 Chest radiographs of patient $5(A)$ with catheter in situ revealing multiple fluid levels before treatment with streptokinase, (B) after two instillations of streptokinase, and (C) 13 weeks after administration of streptokinase.

with myocarditis who was on the waiting list for cardiac transplantation had a pyopneumothorax. Following streptokinase instillation, the empyema drained but the pneumothorax persisted. He therefore underwent surgery for non-resolution of the pneumothorax but died perioperatively from cardiac failure.

The number of streptokinase instillations per patient ranged from two to six with a median
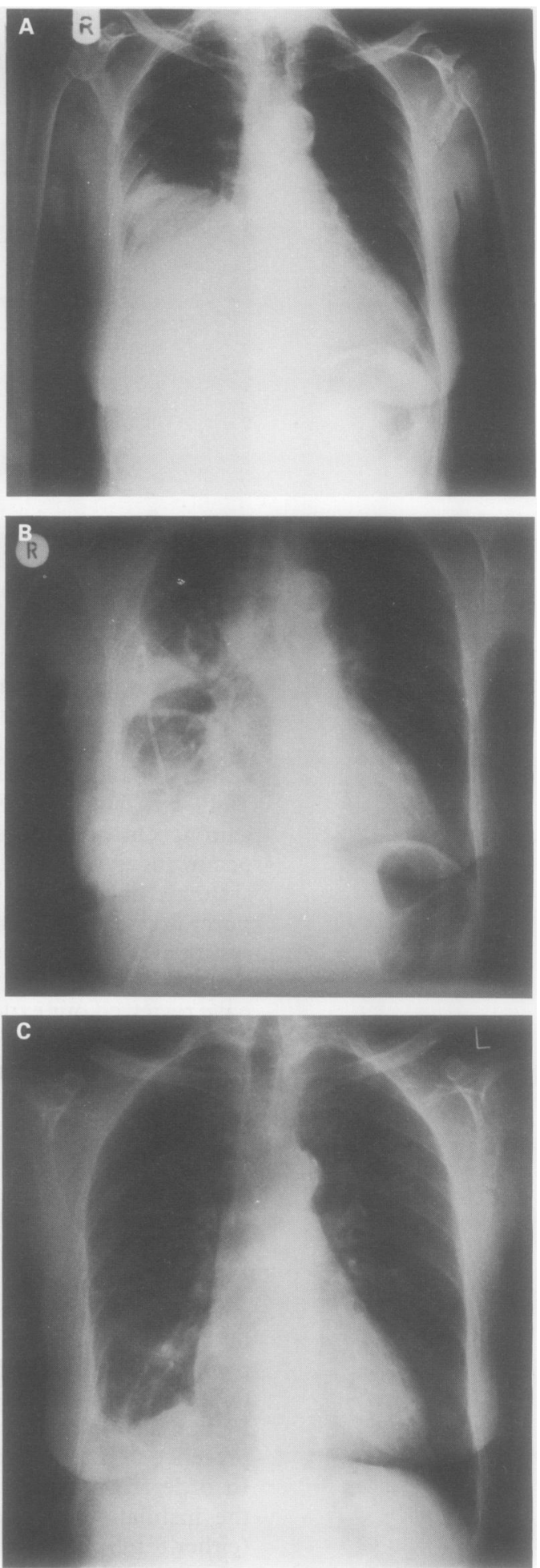

Figure 3 Chest radiographs of patient $11(A)$ at presentation, (B) with catheter in situ before streptokinase administration, and (C) 11 weeks after treatment with streptokinase.

of three. The volume of empyema fluid drained per patient following streptokinase (after subtraction of the injected volumes) ranged from $100 \mathrm{ml}$ to $4870 \mathrm{ml}$ with a median of $900 \mathrm{ml}$ (table). Streptokinase was well tolerated by all patients. One patient, a 74 year old woman, complained of mild ipsilateral chest pain after both instillations of streptokinase. There was no evidence of intrapleural haemorrhage or clinical manifestation of systemic coagulopathy. 


\section{Discussion}

We have given intrapleural streptokinase to 11 patients with empyemas which have not resolved with intercostal tube drainage and antibiotic therapy. The next therapeutic manoevre would usually have been surgery. In our experience streptokinase promoted drainage of loculated empyemas, permitting clinical resolution and obviating thoracic surgery. In view of the considerable morbidity and mortality associated with decortication, ${ }^{9}$ the application of this non-invasive therapeutic option appears to be beneficial. Streptokinase effected complete resolution of the empyema in two patients (nos 7 and 11) who were at high risk of serious morbidity and mortality if they had undergone thoracotomy and decortication. In two patients, failure of streptokinase to achieve complete clinical resolution may be attributed to considerable pleural thickening which had developed before streptokinase therapy. It seems likely that, if enzymatic therapy is initiated early in the evolution of an empyema - that is, before fibrinopurulence is established and organisation occurs - more extensive surgical procedures could be avoided.

All patients tolerated intrapleural streptokinase well; only one complained of mild chest discomfort shortly after each streptokinase instillation. Other authors ${ }^{10}$ have described the successful use of lignocaine given intrapleurally 15 minutes before streptokinase administration. It is of note that previous reports of anaphylaxis and febrile reactions developed in patients in whom streptokinase had been left in the pleural cavity for longer time periods (up to 24 hours). ${ }^{611}$ It is likely that the shorter instillation time of four hours, combined with the use of only highly purified preparations, contributed to the lack of adverse reactions in this series. As in more recent studies, ${ }^{711}$ intrapleural haemorrhage did not occur. It is of note that steroid cover was not given in anticipation of possible systemic reactions to repeated streptokinase instillations which were given at intervals during a period of 20 and 35 days to two patients (nos 7 and 8 respectively); all such instillations were well tolerated. Radiological intervention with placement of small catheters under ultrasound or fluoroscopic control into specific loculations has optimised the outcome of this technique. Subsequent assessment with serial pleural ultrasound examinations has provided information on the presence or absence of fluid or pleural thickening. Indeed, the success of this technique may be attributed partly to the use of ultrasound guided drainage of large loculations, although it is noteworthy that, in this study, adequate drainage was not achieved by ultrasound guided placement of drains alone.

In summary, intrapleural purified streptokinase may be used as an adjunct to initial chest tube drainage when there is a residual collection of pleural fluid. Streptokinase enhances the drainage of fluid which is loculated or is too viscous to be drained by tube thoracostomy alone. Subsequent surgical intervention is not jeopardised by the prior use of streptokinase. The optimum time for the introduction of intrapleural streptokinase in the medical management of complicated empyema remains controversial. Multicentre controlled trials will be necessary to clarify the role of this technique and such a trial is underway.

1 Strange C, Sahn SA. Management of parapneumonic pleural effusions and empyema. In: Wallace RJ, ed. Infectious disease clinics of North America. Philadelphia: Saunders, 1991:539-59.

2 Landay MJ, Christensen EE, Bynum LJ, Goodman C. Anaerobic pleural and pulmonary infections. AfR 1980; 134:233-40.

3 Tillet WS, Sherry S. The effect in patients of streptococcal fibrinolysin (streptokinase) and streptococcal desoxyribonuclease on fibrinous, purulent and sanguinous oxyribonuclease on fibrinous, purulent and sangu
pleural exudations. $\mathcal{f}$ Clin Invest 1949;28:173-90.

4 Berglin E, Ekroth R. Intrapleural instillation of streptokinase: effects on systemic fibrinolysis. Thorac Cardiovasc Surg 1981;29:124-6.

5 Godley PJ, Bell RC. Major haemorrhage following administration of intrapleural streptokinase. Chest 1984;86: 486-7.

6 Fraedrich G, Hofmann D, Effenhauser P, Jander R. Instillation of fibrinolytic enzymes in the treatment of pleural empyema. Thorac Cardiovasc Surg 1982;30:36-8.

7 Aye RW, Froese DP, Hill LD. Use of purified streptokinase in empyema and haemothorax. Am $\mathcal{F}$ Surg 1991;161: in em-2.

8 Bergh NP, Ekroth R, Larsson S, Nagy P. Intrapleural streptokinase in the treatment of haemothorax and empyema. tokinase in the treatment of haemothorax and
Scand $\mathcal{F}$ Thorac Candiovasc Surg 1977; 11:265-8.

9 Muskett A, Burton NA, Karwande SV, Collins MP. Management of refractory empyema with early decortication. Am $\mathcal{F}$ Surg 1988;156:529-32.

10 Henke CA, Leatherman JW. Intrapleurally administered streptokinase in the treatment of acute loculated nonpurulent parapneumonic effusions $A m$ Rev Respir Dis 1992;145:680-4

11 Tillet WS, Sherry S, Read CT. The use of streptokinasestreptodornase in the treatment of post-pneumonic empyema. $\mathcal{F}$ Thorac Surg 1951;21:275-97. 